\title{
Effect of Cumulus cell co-culture and Protein Supplement on Success of in vitro Fertilization and Development of Pre-implanted Embryos in mice
}

\author{
Muhammad-Baqir M-R. Fakhrildin
}

Department of Reproductive Physiology; Institute for Embryo Research and Infertility Treatment, University of Baghdad, Baghdad, IRAQ Email:art_mbmrfd@yahoo.com

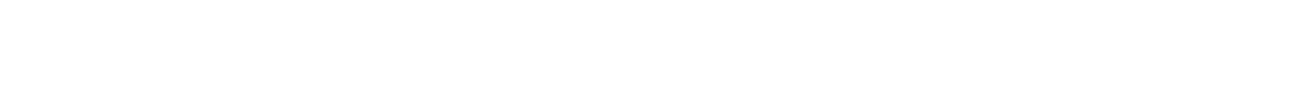
محمد بلفرمحمد وشادفخر الين

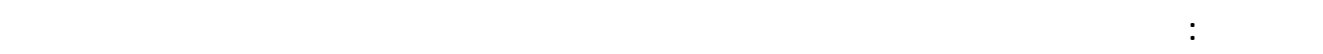

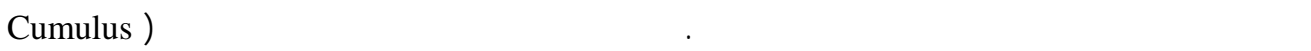

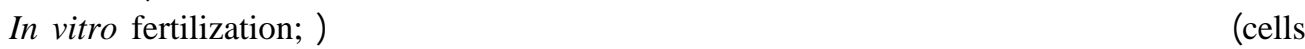
(IVF والطور الطبيعي للمرلطل الجنينية الأولية في الفئران.

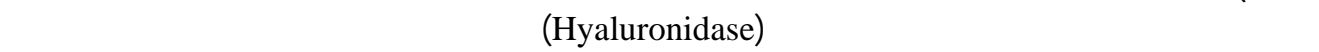

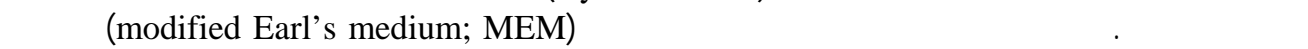

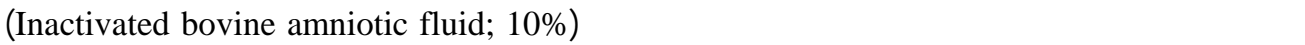

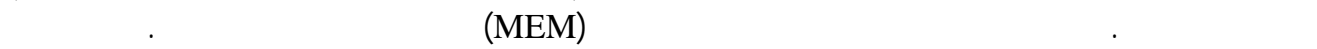

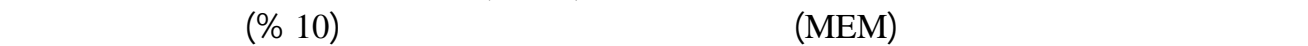



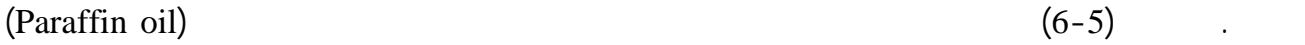

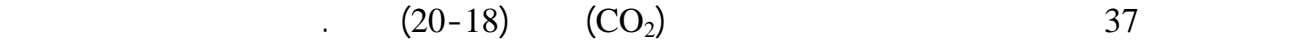
من الأخصلب الخارجي وظور الخمور الأجنة.

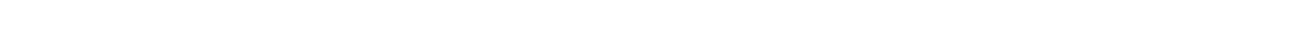

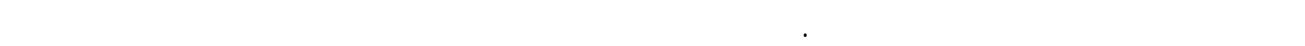

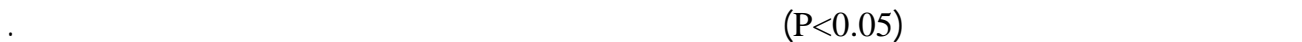

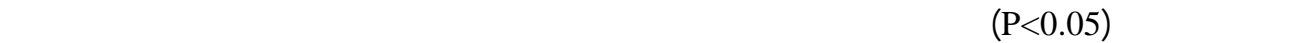
مقارنتها مع بويضلت المجموعة الأولى. 


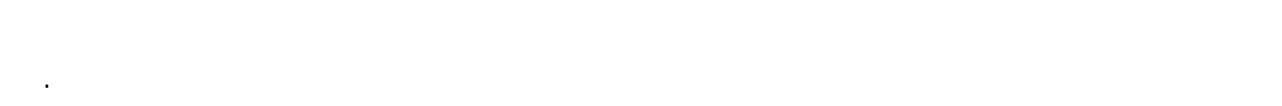

ABSTRACT: Successful oocyte fertilization and normal embryonic development of mice were considered the most important diagnostic criteria for the safety of materials and tools used for human in vitro fertilization and embryo transfer (IVF-ET). Therefore, we studied the influence of cumulus cells co-culture and protein supplement within culture medium on percentages of in vitro fertilization (IVF) and normal development of early stages of mouse embryo later. Oocytes were collected and treated with hyaluronidase to remove cumulus cells. Oocytes were divided into four groups namely: Group-1: Oocytes incubated within modified Earl's medium (MEM) supplied with 10\% inactivated bovine amniotic fluid as a protein source and cumulus cells; Group-2: Oocytes incubated with MEM supplied with cumulus cells only; Group-3: Oocytes incubated with MEM supplied with $10 \%$ inactivated bovine amniotic fluid only; and Group-4: Oocytes incubated with MEM free of both protein source and cumulus cells. For IVF, 5-6 oocytes were incubated with active spermatozoa under paraffin oil for 18-20 hours at $37^{\circ} \mathrm{C}$ in $5 \% \mathrm{CO}_{2}$. Percentages of IVF and embryonic development were then recorded. Best results for IVF and normal embryonic development were achieved from oocytes of Group-1 when compared to the other groups. As compared to Group-1, the percentage of IVF for Group-2 and Group-3 were decreased insignificantly and significantly $(\mathrm{P}<0.002)$, respectively. Significant $(\mathrm{P}<0.01)$ reduction in the percentages of IVF and normal embryonic development were reported in Group-4 as compared to Group-1. Therefore, it was concluded that the presence of cumulus cells co-culture and bovine amniotic fluid as a protein source within culture medium may have an important role on the fertilizing capacity of spermatozoa and oocytes and normal development of pre-implanted mouse embryo later.

KEYWORDS: Mouse, fertilization, embryo, culture medium, IVF.

\section{Introduction}

$\boldsymbol{I}$ $n$ vitro fertilization (IVF) is a procedure that involves retrieving oocytes and spermatozoa from the female and male respectively, and placing them together in a laboratory dish to facilitate fertilization. Fertilized eggs are then allowed to develop in vitro and after several days are transferred into a female's uterus where implantation and embryo development can occur. A number of advances have been made concerning the laboratory aspects of IVF, and one of these advances was the development of better culture media for both fertilization and embryonic growth (Yeung and Ng, 2000).

Bavister (1995) reported that the programs of IVF use different types of culture media based on animal and human studies. However, culture media are classified into two types based on composition. The first one is a simple salt solution formulated with the addition of pyruvate, lactate, glucose and albumin. Others are complex media such as Ham's F-10 which are suitable for long term serum-free cultures and contain nutrients such as vitamins, amino acids and other metabolites (Mahadevan et al. 1997; Duran, 2000).

Certainly, it is important to provide optimum constituents when using in vitro culture techniques to create more natural conditions, which has led to the development of several types of culture media and various additives to optimize fertilization and embryo development (Bae and Foote, 1980; Motlik and Fulka, 1981). Efforts have been made to supplement the culture media with natural additives like serum (Kane and Headon, 1980; Totey et al. 1993), follicular fluid (Calvo et al. 1989), oviductal fluid 


\section{EFFECT OF CUMULUS CO-CULTURE AND PROTEIN SUPPLEMENT}

(Zhu et al. 1994), human tubal fluid (Maeda et al. 1996; Osheroff et al. 1999), cumulus cells (Hartshorne, 1989; Xu et al. 1992; Madan et al. 1994; Watson et al. 1994), granulosa cells (Motlik and Fulka, 1981; Vongpralub and Koyanagi, 1994), and oviductal cells (Minami et al. 1994; Li et al. 2001). However, the use of bovine amniotic fluid as a constituent of culture medium for in vitro maturation, IVF and embryonic development has not been reported, although, amniotic fluid contains different electrolytes, non-protein and protein components (Johnson and Everitt, 1988). But, it was reported that the exact requirements for growing embryos through its different developmental stages are not fully known (Yadav et al. 1998).

The use of pre-implantation mouse embryo culture as a quality control and educational model for technicians to acquire necessary embryo handling skills for human IVF programs has been advocated (Pike and Alikani, 1990). More is known about the embryology of the laboratory mouse than that of any other mammal, and almost all mammalian embryological techniques were originally devised for, and practiced on, the mouse. Even now, only few methods are possible on the mouse, and some other techniques may be less successful in other species (Buehr, 1995). Therefore, this study was designed to investigate the influence of cumulus cells co-culture and bovine amniotic fluid supplemented to the culture medium on the success of IVF and pre-implantation embryonic development in mice.

\section{Materials and Methods}

\subsection{Animals and Superovulation Regimen}

Twenty four healthy, mothered mice (age: 15-16 weeks) of Swiss albino strain were kept in an air-conditioned room at a temperature of $(26+2){ }^{\circ} \mathrm{C}$ and exposed to 12-14 hour day light program (Petter and Pearson, 1971). Females were intraperitoneally (IP) injected with 10 IU of Urofollitrophin FSH-HP (Metrodin, Serono, Italy). 72 hours after the first injection, the same females were injected IP with 10 IU of Chorionic gonadotrophin (Chorulon; Intervet, Holland). Oocytes were flushed by using modified Earl's medium (MEM) (Earl’s Balanced Salts, ICN Flow, ICN Biomedicals Inc., Costa Mesa, CA, USA) from both oviducts 16-18 hours after the last injection, and then treated with hyaluronidase (Medi-Cult, Denmark) to remove cumulus cells. Recovered oocytes were pippeted and washed two times with MEM and classified into immature, mature and atretic depending on the presence of first polar body and morphological features.

\subsection{Cumulus Cells Preparation and Culture}

Cumulus cells were removed from collected oocytes by using hyaluronidase. Cumulus cells were pooled and washed with MEM twice. Then, the cumulus cells were diluted and adjusted to a concentration of $1 \times 10^{5}$ cells/ml. Cumulus cells were cultured according to the procedure reported in details by Weiss and Eckert (1989) with slight modifications.

\subsection{Collection and Preparation of Bovine Amniotic Fluid}

Reproductive systems were obtained from pregnant bovine (10-12 weeks gestation) after slaughter directly, and then transferred to the laboratory within a 1-1.5 hour period. Bovine amniotic fluid (BAF) was collected and centrifuged (1200 g for $15 \mathrm{~min}$. at $4{ }^{\circ} \mathrm{C}$ ) to remove cells and debris. Then, BAF was inactivated at $56{ }^{\circ} \mathrm{C}$ for $30 \mathrm{~min}$. and filtered by using Millipore filter $(0.22 \mu \mathrm{m}$; Acrodisc-DLL, Gelman Sciences). Prepared BAF was divided into aliquots $(10 \mathrm{ml})$ and stored at -4 ${ }^{\circ} \mathrm{C}$ for later use. 


\section{MUHAMMAD-BAQIR M-R. FAKHRILDIN}

\subsection{Experimental Design}

The present study was designed to examine the effects of cumulus cells co-culture and presence of $10 \%$ inactivated bovine amniotic fluid (BAF) as a protein source within MEM on percentages of IVF and normal development of pre-implanted mouse embryos later. Accordingly, oocytes were divided into the following four groups including :

Group-1 (G-1): Oocytes (No. = 108) were incubated with MEM supplied with protein source and cumulus cells;

Group-2 (G-2): Oocytes (No. = 112) were incubated with MEM supplied with cumulus cells only;

Group-3 (G-3): Oocytes (No. = 103) were incubated with MEM supplied with protein source only; and Group-4 (G-4): Oocytes (No. = 113) were incubated with MEM free of both protein source and cumulus cells.

\subsection{Sperm Collection and Function Tests (SFTs)}

Spermatozoa were flushed from both vas deferens of male mouse with $1 \mathrm{ml}$ of sperm preparation medium (Medi-Cult, Denmark). According to the procedure mentioned in-details by Fakhrildin (2000), sperm function tests including sperm concentration, percentage of sperm motility, sperm grade activity and percentage of sperm viability were examined after one hour (Table 1). Then, vassal spermatozoa was adjusted to $5 \times 10^{6}$ sperm / ml within sperm preparation medium.

Table 1. The sperm function tests of vassal spermatozoa after one hour incubation

\begin{tabular}{|l|c|}
\hline \multicolumn{1}{|c|}{ Sperm function tests } & Range \\
\hline Sperm concentration ( X10 $0^{6}$ sperm/ ml) & $26-38$ \\
\hline Percentage of sperm motility & $68-76$ \\
\hline Sperm grade activity & $2.5-3.5$ \\
\hline Percentage of sperm viability & $80-88$ \\
\hline
\end{tabular}

\subsection{In vitro fertilization technique}

For IVF, each 5-6 oocytes $/ 0.5 \mathrm{ml}$ of any group were incubated with active vassal spermatozoa $\left(0.5 \times 10^{6}\right.$ motile sperm $\left./ 0.1 \mathrm{ml}\right)$ under paraffin oil (Medi-Cult, Denmark) for $18-20$ hour at $37^{\circ} \mathrm{C}$ in $5 \% \mathrm{CO}_{2}$. The culture medium for each of four types was changed for in vitro developed embryos two times daily. Percentages of IVF and embryonic development were recorded.

\subsection{Statistics}

Data are presented as mean and standard error of mean (SEM). The data were statistically analyzed by using Chi-square test to compare the level of significance among different means of each group (SPSS Data Editor).

\section{Results}

\subsection{Percentages of in vitro Fertilization (IVF)}

The results of the present study show that the highest percentage of IVF for oocytes was obtained with MEM supplied with cumulus cells co-culture and inactivated bovine amniotic fluid as a protein source (group-1). The percentage of IVF for oocytes of group-1 have either insignificant differences as compared to group-2, or significant $(\mathrm{P}<0.01)$ differences as compared to group-3 and 


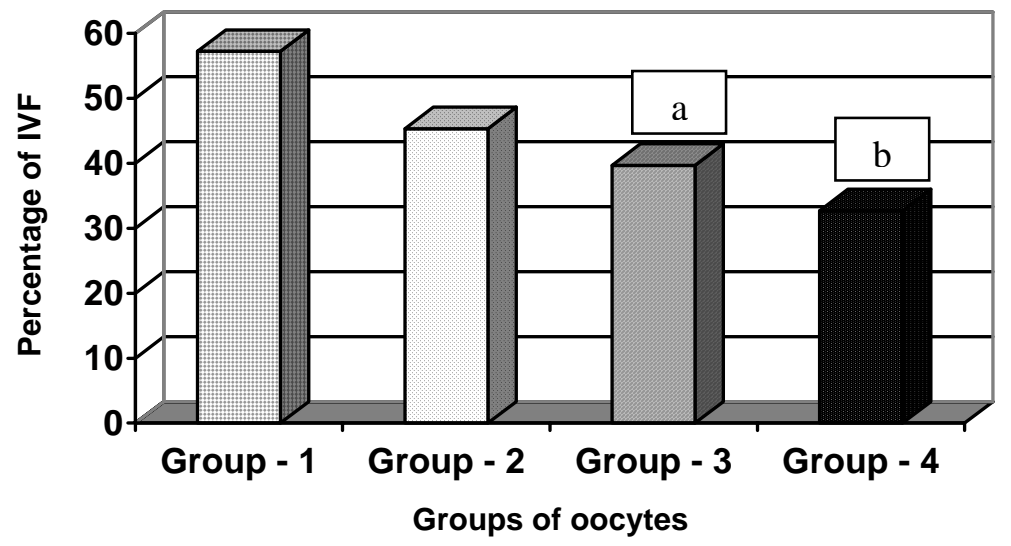

Figure 1. Percentages of IVF for oocytes divided according to the presence of cumulus cells and/or protein source in culture medium. a: Means significantly $(\mathrm{P}<0.01)$ decreased when compared to group-1. b: Means significantly $(\mathrm{P}<0.03)$ decreased when compared to groups-2 and 3.

group-4 (Figure 1). However, there were insignificant differences in the percentages of IVF between oocytes of group-2 and group-3.

The lowest percentage of IVF was recorded for the oocytes which were cultured with MEM without the presence of cumulus cells co-culture and protein source (group-4) when compared to other groups (1, 2 and 3 ) of oocytes (Figure 1).

\subsection{Percentages of Progressive Embryonic Development}

The progressive development of pre-implanted embryos is presented in table 2. Best embryonic development was recorded in the group- 1 oocytes where more than $24 \%$, $31 \%$ and $21 \%$ of produced embryos were developed into 8 cells, 16 cells and 32 cells embryonic stages; respectively. Meanwhile in the same embryonic stages, it was noticed that the lowest embryonic development occurred in oocytes of group-4.

Table 2. Percentages of embryonic development produced from groups of oocytes, divided according to the presence of cumulus cells and/or protein source in culture medium

\begin{tabular}{|l|c|c|c|c|c|c|c|c|}
\hline Groups of & IVF & \multirow{2}{*}{$\begin{array}{c}\text { No. of } \\
\text { ooytes }\end{array}$} & \multicolumn{6}{|c|}{ Percentages of embryonic development } \\
\cline { 5 - 10 } & & developed & \multicolumn{1}{|c}{$\begin{array}{c}1- \\
\text { embryos }\end{array}$} & $\begin{array}{c}\text { cell } \\
\text { cells }\end{array}$ & $\begin{array}{c}4- \\
\text { cells } \\
\text { embryo }\end{array}$ & $\begin{array}{c}8- \\
\text { embryo } \\
\text { eells } \\
\text { embryo }\end{array}$ & $\begin{array}{c}16- \\
\text { cells } \\
\text { embryo }\end{array}$ & $\begin{array}{c}32- \\
\text { ce } \\
\text { lls } \\
\text { embryo }\end{array}$ \\
\hline Group-1 & 57.24 & 62 & 1.61 & 9.68 & 12.90 & 24.19 & 30.64 & 20.98 \\
\hline Group-2 & 45.33 & 51 & 7.84 & 29.41 & 23.53 & 21.57 & 9.80 & 7.85 \\
\hline Group-3 & 39.70 & 41 & 4.88 & 9.76 & 21.95 & 21.95 & 26.83 & 14.63 \\
\hline Group-4 & 32.69 & 36 & 15.79 & 28.95 & 26.32 & 21.05 & 7.89 & 0 \\
\hline
\end{tabular}




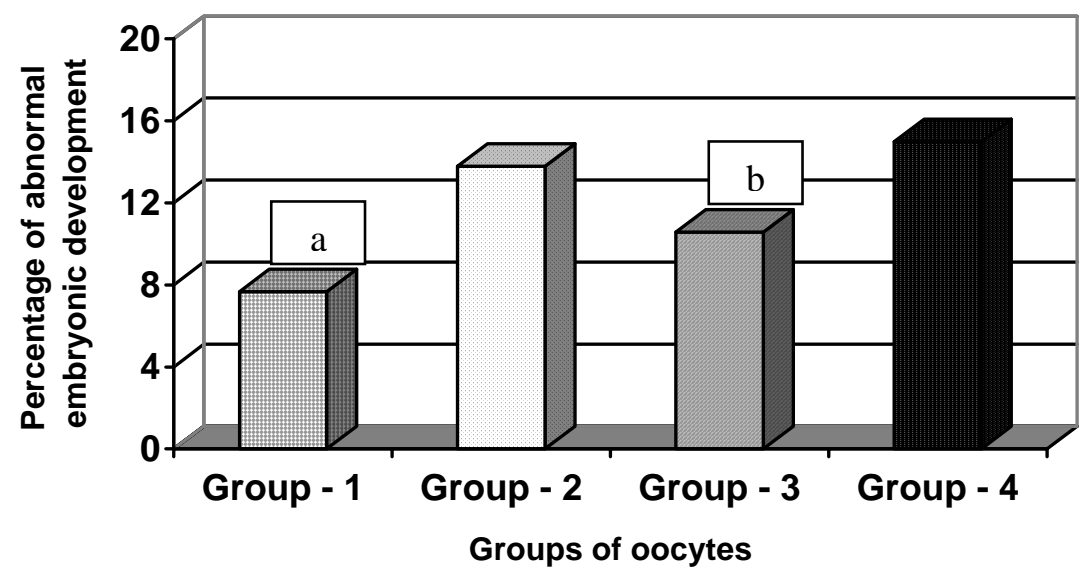

Figure 2. Percentages of abnormal produced from groups of oocytes were divided according to presence of cumulus cells and/or protein source in culture medium a: Means significantly $(\mathrm{P}<0.01)$ decreased when compared to groups-2 and 4 . b: Means significantly $(\mathrm{P}<0.05)$ decreased when compared to groups- 2 and 4.

In general, the oocytes of group-3 embryos developed into 8 cells, 16 cells and 32 cells embryonic stages better than the embryos which developed from oocytes of group- 2 and group- 4 (Table 2).

\subsection{Percentages of Abnormal Embryonic Development}

Figure 2 shows the percentages of abnormal embryonic development produced from four different groups of oocytes. Significant $(\mathrm{P}<0.01)$ reduction in the percentages of abnormal embryonic development was observed in the oocytes of group-1 and group-3 as compared to oocytes of group-2 and group-4. Non significant differences were observed in the percentages of abnormal embryonic development produced from oocytes of group-1 and group-3. Also, insignificant differences were found in the percentages of abnormal embryonic development between group- 2 and group- 4 oocytes.

\section{Discussion}

Since the earlier works of Steptoe and Edwards in in vitro fertilization (IVF) (Steptoe and Edwards, 1978), numerous modifications have been introduced to the different stages of the technique. IVF and embryo transfer has become a widely accepted clinical method for the treatment of infertility, both for economic and academic purposes (Diedrich et al. 1988). Successful IVF requires appropriate preparation of sperm and oocyte, as well as culture conditions that are favorable to the metabolic activity of the male and female gametes (Duran, 2000). Because of the importance of the culture media for in vitro oocyte maturation, sperm preparation, in vitro fertilization and embryonic development (Pike and Alikani, 1990), considerable changes in composition and preparation of culture media, involving addition of the biological fluids and co-culture with granulose cells or oviductal cells or cumulus cells (Maeda et al. 1996; Conaghan et al. 1998), are necessary. The present study was designed to analyze the effects of supplementation of cumulus cells co-culture and inactivated bovine amniotic fluid (BAF) as a protein source with culture medium on percentages of IVF and embryonic development. 


\section{EFFECT OF CUMULUS CO-CULTURE AND PROTEIN SUPPLEMENT}

There are many reasons to select the BAF as a protein source in the present study. The most important reason is that amniotic fluid contains several electrolytes, non-protein and protein components. The concentration of protein content within amniotic fluid is near $3 \%$ (Johnson and Everitt, 1988). Amniotic fluid is produced by the amniotic cells and is derived from maternal blood (Langman, 1981; Moore, 1988). Therefore, some contents of amniotic fluid are similar to maternal serum including albumin, globulin, glucose, prolactin, prostaglandins, estrogens and progesterone (Findlay, 1984; Arici et al. 1999; Yen and Jaffe, 1999).

The results of the present study showed that the highest percentage of IVF for oocytes were cultured with MEM supplied with cumulus cells co-culture and $10 \%$ inactivated BAF as a protein source (group-1). The percentage of IVF for oocytes of group-1 have either insignificant differences as compared to group-2, or significant $(\mathrm{P}<0.01)$ differences as compared to group-3 and group-4 (Figure 1). These results emphasize the major role of cumulus cells co-culture with the culture medium in success of IVF. Also, our results are in agreement with different reports in the literature (Bornslaeger and Schultz, 1985; Hartshorne, 1989; Mori et al. 2000). It is suggested that the cumulus cells synthesize and secrete various substances like progesterone, polypeptides, cytokines, cAMP and MAP kinase which cause final maturation of oocyte, enhance fertilizing capacity of oocytes and spermatozoa and support in vitro development of early stages of embryos (Kol and Adashi, 1995; Shimada et al. 2001; Shimada and Terada, 2002; Su et al. 2002). In the present study, the use of inactivated BAF didn't have any species specific effect and improved the fertilizing capacity of both spermatozoa and oocytes in vitro (Figure 1). Possibly, the presence of several molecules in the $10 \%$ inactivated bovine amniotic fluid may improve the physiology of sperm such as capacitation which is considered the first step for successful fertilization (Osheroff et al. 1999). However, there are no reports or data to show the use of inactivated bovine amniotic fluid with constituents of culture media for IVF and embryonic development.

The lowest percentage of IVF was recorded for oocytes that were cultured with MEM without the presence of cumulus cells co-culture and protein source (group-4) when compared to other groups (1, 2 and 3) of oocytes (Figure 1). It therefore appears that MEM has no growth factors or amino acids or hormones or cytokines or any protein source, which is considered very important for IVF and embryonic development. Indeed, the sub-optimal culture conditions are thought to contribute to these poor rates of development and consequently failure, following IVF (Lane and Gardner, 1997; Conaghan et al. 1998).

Best embryonic development was recorded in the group-1 oocytes where more than $24 \%, 31 \%$ and $21 \%$ of produced embryos were developed into 8 cells, 16 cells and 32 cells embryonic stages; respectively. Meanwhile in the same embryonic stages, it was noticed that the lowest embryonic development was accrued from oocytes of group-4 (Table 2). Supplementation of the culture medium with both inactivated BAF and cumulus cells co-culture may have a direct or synchronized effect to enhance in vitro development of the embryonic stages. The presence of somatic cell monolayer in the culture medium during in vitro culture of the developing embryo was found to be very important in enhancing its development potential, which provides the developing zygotes with a suitable environment, and secretes some growth factors, or autocrine factors or has paracrine effect and balanced electrolytes support further in vitro development (Funahashi et al. 1997; Canipari, 2000; Duran, 2000; Emery et al. 2001).

The embryos that were produced from oocytes of group-3 developed into 8 cells, 16 cells and 32 cells embryonic stages were better than the embryos that were developed from oocytes of group- 2 and group-4 (Table 2). These results demonstrated the significant role of protein source to support progressive growth and embryonic development. In contrast, it was reported that there was no significant difference in the proportion of embryos that continued to develop between the protein-free and protein-supplemented culture media, but no blastocysts in the protein-free medium hatched and only those embryos in protein-containing medium hatched that were from the zona pellucida (Pike 


\section{MUHAMMAD-BAQIR M-R. FAKHRILDIN}

and Alikani, 1990). The presence of cumulus cells with culture medium only did not improve embryonic development, possibly as a result of the release of toxic metabolites or reduction of $\mathrm{O}_{2}$ which led to rapid $\mathrm{O}_{2}$ deprivation of the embryo. However, it remains possible that the local concentration of $\mathrm{O}_{2}$ and lactic acid as well as a reduction in the partial pressure of $\mathrm{O}_{2}$ may cause irreparable damage to the embryos during incubation (Barbehenn et al. 1974).

Significant $(\mathrm{P}<0.01)$ reduction in the percentages of abnormal embryonic development was observed from the oocytes of group- 1 and group-3 as compared to oocytes of group- 2 and group- 4 . Also, non significant differences were observed in the percentages of abnormal embryonic development produced from oocytes of group-1 and group-3 (Figure 2). These results indicate the importance and role of inactivated bovine amniotic fluid throughout progressive in vitro development of normal embryos, because BAF have important nutrients such as hormones, electrolytes, albumin and glucose, as well as the ability to chelate toxic metal ions and pyrogens. Graaff (2002) reported several beneficial functions of amniotic fluid for embryonic development that would ensure symmetrical growth, protection and consistent pressure and temperature.

\section{Conclusion}

It was concluded that the presence of cumulus cells co-culture and inactivated bovine amniotic fluid as a protein source with culture medium has an important role on the fertilizing capacity of spermatozoa and oocytes and normal development of pre-implanted mouse embryos. Inactivated bovine amniotic fluid has no-species-specific effect. Further work is required to assess the effect of cumulus cells co-culture and the presence of protein source with culture medium on implantation rate.

\section{Acknowledgments}

My thanks to the staff of IVF-ET unit for laboratory animals for their assistance with animal maintenance and experimentation during this work.

\section{References}

ARICI, A., BEHRMAN, H.R. and KEEFE, D.L. 1999. Prostaglandins and prostaglandin-like products in reproduction: Eicosanoids, peroxides and oxygen radicals. In: Reproductive Endocrinology. Yen, S.S.C., Jaffe, R.B., Barbiere, R.L. (eds.). W.B. Saunders Company, Pennsylvania, USA. $4^{\text {th }}$ Edition. Pp: 134-152.

BAE, I.H., FOOTE and R.H. 1980. Maturation of rabbit follicular oocytes in a defined medium of varied osmolality. J. Reprod. Fertil. 59: 11-13.

BARBEHENN, E.K., WALES, R.G. and LOWRY, O.H. 1974. The explanation for the blockade of glycolysis in early mouse embryos. Proc. Natl. Acad. Sci. USA. 71: 1056-1060.

BAVISTER, B.D. 1995. Culture of preimplantation embryos: facts and artifacts. Hum. Reprod. Update. 1: 91-148.

BORNSLAEGER, E.A. and SCHULTZ, R.M. 1985. Regulation of mouse oocyte maturation: Effect of elevating cumulus cells cAMP on oocyte cAMP levels. Biol. Reprod. 33: 698-704.

BUEHR, M. 1995. Embryo technology in laboratory animals. Scand. J. Lab. Anim. Sci. 22: 75-85.

CALVO, L., VANTMAN, D., BANKS, S.M., TEZON, J., KOUKOULIS, G.N., DENNISON, L. and SHERINS, R.J. 1989. Follicular fluid-induced acrosome reaction distinguishes a subgroup of men with unexplained infertility not identified by semen analysis. Fertil. Steril. 52: 1048-1054.

CANIPARI, R. 2000. Oocyte-granulosa cell interactions. Hum. Reprod. Update. 6: 279-289. 


\section{EFFECT OF CUMULUS CO-CULTURE AND PROTEIN SUPPLEMENT}

CONAGHAN, J., HARDY, K., LEESE, H.J., WINSTON, R.M.L. and HANDYSIDE, A.H. 1998. Culture of human preimplantation embryos to the blastocyst stage: a comparison of three media. Int. J. Dev. Biol. 42: 885-893.

DIEDRICH, K., VAN DER VEN, H., AL-HASANI, S. and KREBS, D. 1988. Ovarian stimulation for in vitro fertilization. Hum. Reprod. 3: 39-44.

DURAN, D.H. 2000. Technical aspect of in vitro embryo production. Internet file, 1-10.

EMERY, B., MILLER, R. and CARRELL, D.T. 2001. Hamster oocyte membrane potential and ion permeability vary with preantral cumulus cell attachment and developmental stage. BMC Develop. Biol. 1: 14-22.

FAKHRILDIN, M-B. M-R. 2000. Materials and Methods. In: The impact of seminal fluid infections and treatment on sperm functions and fertilizing capacity in infertile patients. Ph. D. Thesis. College of Science, Al-Mustansiriya. Pp: 72-84.

FINDLAY, A.L.R. 1984. The fetus and neonate. In: Reproduction and the fetus. Hardy, R.N., Hobsley, M., Saunders, K.B., Fitzsimons, J.T. (eds.). Edward Arnold (Publishers) Ltd. London, UK. pp: 96-129.

FUNAHASHI, H., CANTLY, T.C. and DAY, B.N. 1997. Synchronization of meiosis in porcine oocytes by exposure to dibutyryl cAMP improves developmental competence following in vitro fertilization. Biol. Reprod. 57: 49-53.

GRAAFF, V.D. 2002. Extraembryonic membranes. Development. $6^{\text {th }}$ Edition. Chapter 22; pp: 754767 (250lec4.html).

HARTSHORNE, G.M. 1989. Steroid production by the cumulus: relationship to fertilization in vitro. Hum. Reprod. 4: 742-745.

IVF.HTM; Internet file. In vitro fertilization: An overview for high school students. P: 1-8.

JOHNSON, M. and EVERITT, B. 1988. The fetus and its preparations for birth. In: Essential Reproduction. Johnson, M., Everitt, B., (eds.). $3^{\text {rd }}$ Edition. Blackwell Scientific Publications. Oxford, UK. Pp: 265-293.

KANE, M.T. and HEADON, D.R. 1980. The role of commercial bovine serum albumin preparations in the culture of one-cell rabbit embryos to blastocysts. J. Reprod. Fertil. 60: 469-475.

KOL, S. and ADASHI, E.Y. 1995. Intraovarian factors regulating ovarian function. Curr. Opin. Obstet. Gynecol. 7: 209-213.

LANE, M. and GARDNER, G.K. 1997. Differential regulation of mouse embryo development and viability by amino acids. J. Reprod. Fert. 109: 153-164.

LANGMAN, J. 1981. Fetal membranes and placenta. In: Medical embryology. Langman, J., (ed.). Williams and Wilkins Company, Baltimore, USA. $4^{\text {th }}$ Edition. Pp: 83-101.

LI, X., MORRIS, L.A-H. and ALLEN, W.R. 2001. Influence of co-culture during maturation on the developmental potential of equine oocytes fertilized by intracytoplasmic sperm injection. Reprod. 121: 925-932.

MADAN, M.L., CHAUHAN, M.S., SINGLA, S.K. and MANIK, R.S. 1994. Pregnancies established from water buffalo (Bubalus bubalis) blastocysts derived from in vitro matured, in vitro fertilized oocytes and co-cultured with cumulus and oviductal cells. Theriogenology 42: 591600.

MAEDA, J., KOTSUJI, F., NEGAMI, A., KAMITANI, N. and TOMINAGA, T. 1996. In vitro development of bovine embryos in conditioned media from bovine granulosa cells and vero cells cultured in exogenous protein- and amino acid-free chemically defined human tubal fluid medium. Biol. Reprod. 54: 930-936.

MAHADEVAN, M., MILLER, M.M. and MOUTOS, D.M. 1997. Absence of glucose decreases human fertilization and sperm movement characteristics in vitro. Hum. Reprod. 12: 119-123. 


\section{MUHAMMAD-BAQIR M-R. FAKHRILDIN}

MINAMI, N., KATO, H., INOUE, Y., YAMADA, M., UTSUMI, K. and IRITANI, A. 1994. Non species specific effect of mouse oviducts on the development of bovine IVM/IVF embryos by a serum free co-culture. Theriogenology 41: 1435-1445.

MOORE, K.L. 1988. Placenta and fetal membranes. In: Essentials of human embryology. Moore, K.L., (ed.). B. C. Decker Inc., Ontario, Canada. pp: 43-52.

MORI, T., AMANO, T. and SHIMIZU, H. 2000. Roles of gap junctional communication of cumulus cells in cytoplasmic maturation of porcine oocytes cultured in vitro. Biol. Reprod. 62: 913-919.

MOTLIK, J. and FULKA, J. 1981. Fertilization of rabbit oocytes co-cultured with granulos cells. $J$. Reprod. Fertil. 63: 425-429.

OSHEROFF, J., VISCONTI, P., VALENZUELA, J.P., TRAVIS A.J., ALVAREZ, J. and KOPF, G.S. 1999. Regulation of human sperm capacitation by a cholesterol efflux-stimulated signal transduction pathway leading to protein kinase A-mediated up-regulation of protein tyrosine phosphorylation. Mol. Hum. Reprod. 5: 1017-1026.

PETER, W. and PEARSON, A.E.G. 1971. The laboratory animals: principles and practice. Academic Press. New York, USA. Pp: 226-234.

PIKE, I.L. and ALIKANI, M. 1990. Time-dependent loss of developmental potential when two-celled mouse embryos were retained in culture in excised oviducts. Ann. New York Acad. Scien. 419423.

SHIMADA, M., MAEDA, T. and TERADA, T. 2001. Dynamic changes of connexin-43, gap junctional protein, in outer layers of cumulus cells are regulated by PKC and PI 3-kinase during meiotic resumption in porcine oocytes. Biol. Reprod. 64: 1255-1263.

SHIMADA, M. and TERADA, T. 2002. FSH and LH induce progesterone production and progesterone receptor synthesis in cumulus cells, a requirement for meiotic resumption in porcine oocytes. Mol. Hum. Reprod. 8: 612-618.

STEPTOE, P.C. and EDWARDS, R.G. 1978. Birth after the re-implantation of a human embryo. Lancet 2: 336-341.

SU, Y-Q., WIGGLESWORTH, K., PENDOLA, F.L., O’BRIEN, M.J. and EPPIG, J.J. 2002. Mitogenactivated protein kinase activity in cumulus cells is essential for gonadotropin-induced oocyte meiotic resumption and cumulus expansion in the mouse. Endocrinology 143: 2221-2232.

TOTEY, S.M., PAWSHE, C.H. and SINGH, G.P. 1993. In vitro maturation and fertilization of buffalo oocytes (Bubalus bubalis): Effect of media hormone and sera. Theriogenology 39: 11351171.

VONGPRALUB, T. and KOYANAGI, F. 1994. Effects of oxytocin and granulose cell co-culture on the development of mouse one-cell stage embryos. J. Mamm. Ova. Res. 11: 175-181.

WATSON, A.J., WATSON, P.H., WARNES, D., WALKER, S.K., ARMSTRONG, D.T. and SEAMARK, R.F. 1994. Preimplantation development of in vitro matured and in vitro fertilized ovine zygotes. Comparison between co-culture on oviduct epithelial cell monolayer and culture under low oxygen atmosphere. Biol. Reprod. 50: 715-724.

WEISS, T. and ECKERT, A. 1989. Cotinine levels in follicular fluid and serum of IVF patients: effect on granulose-luteal cell function in vitro. Hum. Reprod. 4: 482-485.

XU, K.P., YADAF, B.R., RORIE, R.W., PLANTE, L., BETTERIDGE, K.J. and KING, W.A. 1992. Development and viability of bovine embryos ferived from oocytes matured and fertilized in vitro and co-culture with bovine oviductal epithelial cells. J. Reprod. Fertil. 94: 33-43.

YADAV, P.S., SAINI, A., KUMAR, A. and JAIN, G.C. 1998. Effect of oviductal cell co-culture on cleavage and development of goat IVF embryos. Animal Reprod. Science 51: 301-306.

YEN, S.S.C. and JAFFE, R.P. 1999. Prolactin in human reproduction. In: Reproductive Endocrinology. Yen, S.S.C., Jaffe, R.B., Barbiere, R.L., (eds.). W.B. Saunders Company, Pennsylvania, USA. $4^{\text {th }}$ Edition. Pp: 257-283. 
YEUNG, W.S.B. and NG, E.H.Y. 2000. Laboratory aspects of assisted reproduction. HKMJ. 6: 163168.

ZHU, J., BARRAT, C.L.R., LIPPES, J., PACEY, A.A., LENTON, E.A. and COOKE, I.D. 1994. Human oviductal fluid prolongs sperm survival. Fertil. Steril. 61: 360-366.

Received 19 January 2005

Accepted 30 June 2005 